\title{
ANALISIS KUALITAS LAYANAN PELANGGAN UNTUK PRODUK INDIHOME DI TELKOM WITEL SIDOARJO
}

\author{
Nanang Agustian1, Dini Retnowati ${ }^{2}$ \\ e-mail : nanang900811@gmail.com,dini_retnowati@dosen.umaha.ac.id \\ Fakultas Teknik, Jurusan Teknik Industri, Universitas Maarif Hasyim Latif \\ Jl. Ngelom Megare, Taman Sidoarjo 61257
}

\begin{abstract}
ABSTRAK
Mulai dari tahun 2015 hingga tahun 2017, Indihome mengalami masalah penurunan jumlah pelanggan. Oleh karena itu, peningkatan kualitas layanan Indihome sangat di perlukan di TELKOM, jika indihome memberikan kualitas layanan yang baik dan memuaskan akan menghasilkan pelanggan yang loyal, bahkan tidak akan mudah untuk beralih dan menggunakan produk competitor yang lain khususnya untuk pelanggan eksisting. Dalam penelitian ini, digunakan metode QFD yaitu suatu alat yang digunakan untuk merancang suatu proses sebagai tanggapan terhadap kebutuhan pelanggan yang fokus utamanya melibatkan pelanggan pada proses pengembangan produk sedini mungkin. Dari keseluruhan penelitian ini mendapatkan hasil yang dapat direkomendasikan sebagai langkah-langkah perbaikan yang perlu dilakukan yaitu : menambah dan memperbaiki kualitas layanan sesuai dengan goal yang diperoleh dengan membandingkan hasil kuesioner untuk kepuasan pelanggan yaitu didapatkan nilai rata-rata 4.09 dan di dapatkan respon prioritas dengan nilai Absolute Importance sebesar 155,43 di respon teknis pemasangan instalasi jaringan fiber optik sesuai dengan spesifikas, sebesar 145.44 pada respon teknis adanya perangkat cadangan disetiap STO dan sebesar 75.42 pada respon teknis penerapan iso pada security
\end{abstract}

Kata kunci: Indihome, Kualitas layanan, Quality Function Deployment.

\section{PENDAHULUAN}

Saat ini Indihome mengalami masalah penurunan jumlah pelanggan. Data tahun 2015 menunjukan jumlah pelanggan yang mengajukan pemakaian produk indihome sebesar 24.658 pelanggan, pada tahun 2016 mengalami penurunan menjadi sebesar 9.599 pelanggan dan hingga tahun 2017 jumlah pengajuan pemakaian tetap menurun. Oleh karena itu peningkatan kualitas layanan Indihome sangat diperlukan di TELKOM. Jika indihome memberikan kualitas layanan yang baik dan memuaskan maka akan menghasilkan pelanggan yang loyal, bahkan tidak akan mudah untuk beralih dan menggunakan produk competitor yang lain khususnya untuk pelanggan eksisting.

Diharapkan juga dengan kualitas layanan yang baik akan menghindarkan TELKOM dari perang harga untuk mendapatkan pelanggan baru maupun mempertahankan pelanggan lama yang sudah memakai Indihome. Walaupun saat ini menurut (Rowter, 2017) masih banyak perusahaan operator penyedia layanan broadband yang berlomba-lomba memberikan harga serendah mungkin, tetapi tidak di imbangi dengan peningkatan kualitas layanan yang seharusnya menjadi senjata utama untuk perusahaan jasa. Perang harga ini, nantinya pun bisa berdampak pada kebangkrutan perusahaan operator itu sendiri.

Berdasarkan pada permasalahan diatas maka perbaikan kualitas layanan pelanggan WITEL Sidoarjo perlu dilakukan supaya bisa menaikkan jumlah pelanggan yang dimiliki. Penelitian ini menggunakan metode Quality Function Deployment (QFD). Di harapkan dengan pendekatan metode QFD ini, dapat digunakan untuk merancang suatu proses sebagai tanggapan terhadap kebutuhan pelanggan yang fokus utamanya melibatkan pelanggan pada proses pengembangan produk sedini mungkin sehingga kualitas layanan yang diberikan perusahaan akan sesuai dengan kebutuhan pelanggan (Karuniawati.,Supriyanto, Hari., 2005).

\section{METODE PENELITIAN}

Berikut ini adalah langkah-langkah yang dilakukan pada tahapan pengumpulan dan pengolahan data :

1. Kajian Literatur dan Studi Lapangan

2. Identifikasi dan Perumusan Masalah

3. Menentukan Tujuan Penelitian

4. Pengambilan Data

5. Penentuan Jumlah Sampel

Dalam penelitian ini ukuran sampel ditentukan berdasarkan sampel awal (presampling) yang disebarkan, yaitu 30 kuesioner. Pada tahap pengumpulan kuesioner, dipisahkan antara kuesioner yang lengkap dan tidak ada keraguan dengan kuesioner yang tidak lengkap dan terdapat keraguan hasil pengisian kusioner 
oleh responden. Pada tahap pre-sampling ini terkumpul yang layak diolah adalah 28 kuesioner, sehingga ada 2 kuesioner yang tidak layak atau terdapat keraguan, proporsi kuesioner yang layak (p) adalah $\frac{28}{30}=0,93$ dan proporsi kuesioner yang tidak layak (q) adalah $1-0,93=0,07$ atau $\frac{2}{30}=0,07$. Dengan $\alpha$ sebesar 0,1 (10\%) dan $e$ sebesar 0,05, maka jumlah sampel minimal yang diambil (dengan menggunakan persamaan Bernoulli) adalah (Sugiono, 2014) :

$$
\begin{aligned}
\mathrm{n}= & \frac{Z_{\alpha / 2}{ }^{2} \cdot p \cdot q}{e^{2}} \\
& \frac{(1,96)^{2} \cdot 0,93 \cdot 0,07}{(0,05)^{2}} \\
\mathrm{n} & =100
\end{aligned}
$$

Maka sample minimum dari penelitian ini adalah 100 kuesioner.

6. Menyusun dan Penyebaran Kuesioner Awal Penyusunan kuisioner dilakukan untuk mengetahui Voice of Customer terhadap produk Telkom Indihome di witel Sidoarjo

7. Uji Validitas dan Reliabilitas

Pengujian validitas dan reliabilitas dilakukan menggunakan program spss terhadap kuesione yang diajukan kepada responden.

8. Penyebaran kuesioner akhir
Setelah melakukan uji vaiditas dan reliabilitas data, selanjutnya dilakukan penyusunan kuesioner ahkir dengan menghilangkan faktor-faktor dari kebutuhan pelanggan yang dianggap tidak valid. Dalam kuesioner ini selain menentukan tingkat kepentingan pelanggan, juga menentukan tinggkat kepuasan pelanggan yang di ukur dengan metode skala likert

9. Implementasi Metode QFD

Menurut (Cohen, 1995) tahapan implementasi QFD ada 3 yaitu

a. Tahap pengumpulan voice of customer

b. Tahap penyusunan rumah kualitas (House of Quality)

c. Tahap analisa dan implementasi

\section{HASIL DAN PEMBAHASAN}

Ada 18 atribut pernyataan yang diajukan kepada para responden melalui kuesioner. Kuesioner ini diajukan bertujuan untuk mencari tahu kepuasan pelanggan terhadap layanan broadband yang diberikan serta untuk mengetahui posisi layanan broadband yang diberikan Indihome bila dibandingkan dengan penyedia layanan broadband lainnya. Oleh karena itu, responden yang mengisi kuesioner ini adalah responden yang pernah berlangganan layanan broadband baik dari penyedia operator layanan broadband MNC, First Media dan juga Indihome. Data hasil kuesioner kemudian diuji validitas dan reliabilitasnya. Tabel berikut ini

\begin{tabular}{|c|c|c|c|c|c|}
\hline \multirow[t]{2}{*}{ No. } & \multirow[t]{2}{*}{ Pernyataan } & \multicolumn{3}{|c|}{ r hitung } & \multirow[t]{2}{*}{ r tabel } \\
\hline & & indihome & MNC & $\begin{array}{c}\text { First } \\
\text { media }\end{array}$ & \\
\hline 1. & Layanan Broadband sudah menggunakan 100\% Fiber optik & 0.26 & 0.62 & 0.37 & 0.19 \\
\hline 2. & $\begin{array}{l}\text { Fasilitas Broadband memiliki Internet yang lancar dan Chanel Tv yang sangat } \\
\text { lengkap }\end{array}$ & 0.36 & 0.70 & 0.46 & 0.19 \\
\hline 3. & Tarif yang di tawarkan sangat terjangkau & 0.24 & 0.44 & 0.53 & 0.19 \\
\hline 4. & Karyawan berpenampilan rapi, menarik dan memiliki attitude yang baik & 0.43 & 0.52 & 0.40 & 0.19 \\
\hline 5. & Performansi jaringan luas, lancar dan tidak ada gangguan & 0.27 & 0.28 & 0.62 & 0.19 \\
\hline 6. & Kemudahan dan kecepatan administrasi saat melakukan transaksi pembayaran & 0.28 & 0.62 & 0.62 & 0.19 \\
\hline 7. & Proses pemasangan sangat mudah dan cepat & 0.41 & 0.58 & 0.58 & 0.19 \\
\hline 8. & Selalu tepat waktu dalam memberikan pelayanan & 0.48 & 0.59 & 0.57 & 0.19 \\
\hline 9. & $\begin{array}{l}\text { Layanan yang diperoleh pelanggan sesuai dengan informasi dan promo yang } \\
\text { diberikan }\end{array}$ & 0.46 & 0.69 & 0.65 & 0.19 \\
\hline 10 & $\begin{array}{l}\text { Karyawan melayani dengan ramah terhadap informasi yang di butuhkan pelanggan } \\
\text { melalui call center yang telah tersedia }\end{array}$ & 0.60 & 0.70 & 0.42 & 0.19 \\
\hline 11 & $\begin{array}{l}\text { Cepat dan tanggap dalam merespon keluhan atau gangguan layanan di } \\
\text { pelanggan }\end{array}$ & 0.20 & 0.63 & 0.27 & 0.19 \\
\hline 12 & Tanggap dalam memberikan informasi dan promo terbaru terhadap pelanggan & 0.45 & 0.39 & 0.20 & 0.19 \\
\hline 13 & $\begin{array}{l}\text { Pelanggan mendapatkan kemudahan dalam melakukan pemutusan berlangganan } \\
\text { sewaktu-waktu }\end{array}$ & 0.34 & 0.63 & 0.26 & 0.19 \\
\hline 14 & Menjamin kemudahan pelanggan untuk update \& upgrade fitur-fitur terbaru & 0.30 & 0.46 & 0.32 & 0.19 \\
\hline
\end{tabular}
menunjukkan hasil uji validitas untuk semua kuesioner.

Tabel 1. Hasil uji validitas kepuasan pelanggan 
Tabel 1. Hasil uji validitas kepuasan pelanggan (Lanjutan)

\begin{tabular}{|c|l|c|c|c|c|}
\hline \multirow{2}{*}{ No } & \multicolumn{1}{|c|}{ Pernyataan } & \multicolumn{3}{|c|}{ r hitung } & r tabel \\
\cline { 3 - 5 } & & indihome & MNC & First \\
media & \\
\hline 15 & Memberikan pergantian perangkatyang rusak secaragratis & 0.47 & 0.62 & 0.37 & 0.19 \\
\hline 16 & Memiliki jam operasi sesuai kebutuhan pelanggan & 0.58 & 0.67 & 0.23 & 0.19 \\
\hline 17 & Memiliki karyawan yang bisa memberikan perhatian secara personal & 0.24 & 0.46 & 0.37 & 0.19 \\
\hline
\end{tabular}

Dari hasil pengolahan data kuesioner dapat dilihat bahwa nilai korelasi tiap atribut jasa pelayanan pada tabel menunjukan $r$ hitung memiliki nilai yang lebih besar jika dibandingkan dengan hasil $r$ tabel dengan taraf signifikan $5 \%$ dengan $\mathrm{N}=100$. Oleh karena itu, 18 pernyataan yang diajukan dalam kuesioner dianggap valid.

Setelah dilakukan uji validitas maka langkah selanjutnya adalah melakukan uji reliabilitas. Pada uji ini dibandingkan antara $\alpha$ yang didapatkan dari perhitungan $r$ tabel dengan $\alpha$ hasil pengujian data melalui software spss. Hasil perhitungan $\alpha$ pada $r$ tabel sebesar 0,6 sedangkan nilai Cronbach's Alpha pada Indihome sebesar $=0.6401$ MNC sebesar $=0.8751$, dan pada First Media sebesar $=0.739$. Karena nilai Cronbach's Alpha $>\alpha$ pada $r$ tabel maka data dianggap reliable.

\section{Matriks perencanaan/ planning matrix}

Matrik perencanan merupakan matrik yang berisi data-data kuantitatif yang penting dari masingmasing keinginan pelanggan, adapun bagian- bagian dari matriks perencanaan adalah sebagai berikut :

1. Tingkat kepentingan pelanggan (Importance to Customer)

Tingkat kepentingan atribut seperti yang ditunjukkan pada tabel 2 adalah nilai yang menunjukan seberapa penting atribut tersebut baik pelanggan Nilai kepentingan yang semakin tinggi berarti atribut tersebut semakin dipentingkan menurut pelanggan. Hasil perhitungan ini adalah berupa bobot dari tiap-tiap atribut

$$
\mathrm{X}=\sum_{j=1}^{j=n} x i j / \mathrm{n}
$$

Tabel 2. Kepentingan Pelanggan Indihome

\begin{tabular}{|c|c|c|c|}
\hline No & Pernyataan & Nilai & Rangking \\
\hline 1 & Layanan Broadband sudah menggunakan $100 \%$ Fiber optik & 4.25 & 5 \\
\hline 2 & $\begin{array}{l}\text { Fasilitas Broadband memiliki Internet yang lancar dan Chanel UseeTv yang sangat } \\
\text { lengkap }\end{array}$ & 4.07 & 1 \\
\hline 3 & Tarif yang di tawarkan sangat terjangkau & 4.13 & 11 \\
\hline 4 & Karyawan berpenampilan rapi, menarik dan memiliki attitude yang baik & 3.97 & 3 \\
\hline 5 & Performansi jaringan luas, lancar dan tidak ada gangguan & 4.48 & 2 \\
\hline 6 & Kemudahan dan kecepatan administrasi saat melakukan transaksi pembayaran & 4.03 & 7 \\
\hline 7 & Proses pemasangan sangat mudah dan cepat & 4.06 & 8 \\
\hline 8 & Selalu tepat waktu dalam memberikan pelayanan & 4.06 & 6 \\
\hline 9 & $\begin{array}{l}\text { Layanan yang diperoleh pelanggan sudah sesuai dengan informasi dan promo yang } \\
\text { diberikan }\end{array}$ & 3.93 & 4 \\
\hline 10 & $\begin{array}{l}\text { Karyawan melayani dengan ramah terhadap informasi yang di butuhkan pelanggan } \\
\text { melalui call center yang telah tersedia }\end{array}$ & 3.89 & 15 \\
\hline 11 & Cepat dan tanggap dalam merespon keluhan atau gangguan layanan di pelanggan & 4.17 & 13 \\
\hline 12 & Tanggap dalam memberikan informasi dan promo terbaru terhadap pelanggan & 3.94 & 12 \\
\hline 13 & $\begin{array}{l}\text { Pelanggan mendapatkan kemudahan dalam melakukan pemutusan berlangganan } \\
\text { sewaktu-waktu }\end{array}$ & 3.95 & 14 \\
\hline 14 & Menjamin kemudahan pelanggan untuk update \& upgrade fitur-fitur terbaru & 3.94 & 9 \\
\hline 15 & Memberikan pergantian perangkat yang rusak secara gratis & 3.97 & 10 \\
\hline 16 & Memiliki jam operasi sesuai kebutuhan pelanggan & 3.89 & 16 \\
\hline 17 & Memiliki karyawan yang bisa memberikan perhatian secara personal kepada pelanggan & 3.87 & 17 \\
\hline 18 & $\begin{array}{l}\text { Karyawan memahami keinginan dan kebutuhan pelanggan terkait informasi dan } \\
\text { komunikasi }\end{array}$ & 3.87 & 18 \\
\hline
\end{tabular}


2. Tingkat kepuasan pelanggan (Customer Satisfaction Performance)

Customer satisfaction performance seperti yang ditunjukkan pada tabel 3 adalah nilai kepuasan dari pelanggan terhadap produk telkom Indihome yang dianalisis pada kondisi sekarang ini. Cara untuk menentukan nilai ini adalah sama dengan langkah sebelumnya yaitu mencari nilai rata-rata untuk masing-masing atribut untuk produk yang dianalisis. Semakin baik pelayanan semakin pelanggan merasa puas untuk produk tersebut.

Tabel 3. Tingkat Kepuasan Yang Diterima Pelanggan Telkom Indihome

\begin{tabular}{|c|l|c|c|}
\hline No & \multicolumn{1}{|c|}{ Pernyataan } & Nilai & Rangking \\
\hline 1 & Layanan Broadband sudah menggunakan 100\% Fiber optic & 4.30 & 2 \\
\hline 2 & $\begin{array}{l}\text { Fasilitas Broadband memiliki Internet yang lancar dan Chanel UseeTv yang sangat } \\
\text { lengkap }\end{array}$ & 4.14 & 5 \\
\hline 3 & Tarif yang di tawarkan sangat terjangkau & 4.25 & 4 \\
\hline 4 & Karyawan berpenampilan rapi, menarik dan memiliki attitude yang baik & 4.06 & 9 \\
\hline 5 & Performansi jaringan luas, lancar dan tidak ada gangguan & 4.69 & 1 \\
\hline 6 & Kemudahan dan kecepatan administrasi saat melakukan transaksi pembayaran & 4.07 & 8 \\
\hline 7 & Proses pemasangan sangat mudah dan cepat & 4.14 & 6 \\
\hline 8 & Selalu tepat waktu dalam memberikan pelayanan & 4.12 & 7 \\
\hline 9 & $\begin{array}{l}\text { Layanan yang diperoleh pelanggan sudah sesuai dengan informasi dan promo yang } \\
\text { diberikan }\end{array}$ & 3.99 & 14 \\
\hline 10 & $\begin{array}{l}\text { Karyawan melayani dengan ramah terhadap informasi yang di butuhkan pelanggan } \\
\text { melalui call center yang telah tersedia }\end{array}$ & 3.97 & 15 \\
\hline 11 & Cepat dan tanggap dalam merespon keluhan atau gangguan layanan di pelanggan & 4.26 & 3 \\
\hline 12 & Tanggap dalam memberikan informasi dan promo terbaru terhadap pelanggan & 4.01 & 12 \\
\hline 13 & $\begin{array}{l}\text { Pelanggan mendapatkan kemudahan dalam melakukan pemutusan berlangganan } \\
\text { sewaktu-waktu }\end{array}$ & 4.02 & 11 \\
\hline 14 & Menjamin kemudahan pelanggan untuk update \& upgrade fitur-fitur terbaru & 4.00 & 13 \\
\hline 15 & Memberikan pergantian perangkat yang rusak secara gratis & 4.06 & 10 \\
\hline 16 & Memiliki jam operasi sesuai kebutuhan pelanggan & 3.96 & 16 \\
\hline 17 & $\begin{array}{l}\text { Memiliki karyawan yang bisa memberikan perhatian secara personal kepada } \\
\text { pelanggan }\end{array}$ & 3.94 & 17 \\
\hline 18 & $\begin{array}{l}\text { Karyawan memahami keinginan dan kebutuhan pelanggan terkait informasi dan } \\
\text { komunikasi }\end{array}$ & 3.58 & 18 \\
\hline
\end{tabular}

3. Data Competitive Satisfaction Performance

Competitive Satisfaction Performance merupakan persepsi konsumen terhadap seberapa baik layanan yang diberikan pesaing guna memuaskan kebutuhan pelanggan. Tujuannya untuk mengetahui kelebihan dari pesaing sekaligus mengetahui tingkat keunggulan kompetitif layanan

Tabel 4. Tingkat Kepuasan Yang Diterima Pelanggan MNC dan First Media

\begin{tabular}{|c|l|c|c|}
\hline No & \multicolumn{1}{|c|}{ Pernyataan } & $\begin{array}{c}\text { Nilai } \\
\text { MNC }\end{array}$ & $\begin{array}{c}\text { Nilai First } \\
\text { Media }\end{array}$ \\
\hline 1 & Layanan Broadband sudah menggunakan 100\% Fiber optik & 3.93 & 3.99 \\
\hline 2 & $\begin{array}{l}\text { Fasilitas Broadband memiliki Internet yang lancar dan Chanel UseeTv yang sangat } \\
\text { lengkap }\end{array}$ & 4.05 & 4.31 \\
\hline 3 & Tarif yang di tawarkan sangat terjangkau & 4.17 & 4.26 \\
\hline 4 & Karyawan berpenampilan rapi, menarik dan memiliki attitude yang baik & 3.96 & 4.11 \\
\hline 5 & Performansi jaringan luas, lancar dan tidak ada gangguan & 4.62 & 4.03 \\
\hline 6 & Kemudahan dan kecepatan administrasi saat melakukan transaksi pembayaran & 4.02 & 4.09 \\
\hline 7 & Proses pemasangan sangat mudah dan cepat & 3.96 & 4.09 \\
\hline
\end{tabular}

Broadband yang telah diberikan oleh Telkom Indihome kepada pelangganya. Pesaing yang dianggap sebagai pembanding adalah First Media dan MNC karena kedua provider tersebut memiliki jumlah pelanggan yang cukup banyak. 
Tabel 4. Tingkat Kepuasan Yang Diterima Pelanggan MNC dan First Media (Lanjutan)

\begin{tabular}{|c|l|c|c|}
\hline No & \multicolumn{1}{|c|}{ Pernyataan } & $\begin{array}{c}\text { Nilai } \\
\text { MNC }\end{array}$ & $\begin{array}{c}\text { Nilai First } \\
\text { Media }\end{array}$ \\
\hline 8 & Selalu tepat waktu dalam memberikan pelayanan & 4.00 & 4.07 \\
\hline 9 & $\begin{array}{l}\text { Layanan yang diperoleh pelanggan sudah sesuai dengan informasi dan promo yang } \\
\text { diberikan }\end{array}$ & 3.84 & 4.16 \\
\hline 10 & $\begin{array}{l}\text { Karyawan melayani dengan ramah terhadap informasi yang di butuhkan pelanggan } \\
\text { melalui call center yang tersedia }\end{array}$ & 4.05 & 3.97 \\
\hline 11 & Cepat dan tanggap dalam merespon keluhan atau gangguan layanan di pelanggan & 3.97 & 3.84 \\
\hline 12 & Tanggap dalam memberikan informasi dan promo terbaru terhadap pelanggan & 4.14 & 4.17 \\
\hline 13 & $\begin{array}{l}\text { Pelanggan mendapatkan kemudahan dalam melakukan pemutusan berlangganan } \\
\text { sewaktu-waktu }\end{array}$ & 3.97 & 3.81 \\
\hline 14 & Menjamin kemudahan pelanggan untuk update \& upgrade fitur-fitur terbaru & 3.96 & 4.06 \\
\hline 15 & Memberikan pergantian perangkat yang rusak secara gratis & 4.02 & 4.01 \\
\hline 16 & Memiliki jam operasi sesuai kebutuhan pelanggan & 4.06 & 4.05 \\
\hline 17 & Memiliki karyawan yang bisa memberikan perhatian secara personal kepada pelanggan & 4.00 & 4.01 \\
\hline 18 & $\begin{array}{l}\text { Karyawan memahami keinginan dan kebutuhan pelanggan terkait informasi dan } \\
\text { komunikasi }\end{array}$ & 4.02 & 3.97 \\
\hline
\end{tabular}

4. Penetapan nilai Goal

Goal merupakan target yang akan dijadikan tujuan pencapaian tingkat performansi dari pelayanan Indihome yang dianalisis dan disesuaikan dengan sumber daya yang dimiliki perusahaan. Penetapan besarnya nilai goal ini berdasarkan nilai yang ingin dicapai, tidak terlampau tinggi dan minimal adalah sama dengan kompetitor yang lain. Sehingga paling tidak bisa mengurangi kesenjangan dengan kompetitor yang lain. Goal dapat dijadikan sebagai tujuan jangka panjang dalam pelayanan yang dberikan oleh indihome. Nilai Goal ditunjukkan dalam tabel 5 dibawah ini.

\section{Improvement Ratio}

Semakin tinggi nilai rasio pengembangan menunjukkan semakin besar usaha yang dibutuhkan mencapai target.

Tabel 5. Improvement Ratio

\begin{tabular}{|c|l|c|c|c|}
\hline No & \multicolumn{1}{|c|}{ Pernyataan } & CSP & Goal & Nilai IR \\
\hline 1 & Layanan Broadband sudah menggunakan 100\% Fiber optik & 4.30 & 4.30 & 1.000 \\
\hline 2 & $\begin{array}{l}\text { Fasilitas Broadband memiliki Internet yang lancar dan Chanel UseeTv yang sangat } \\
\text { lengkap }\end{array}$ & 4.14 & 4.31 & 1.041 \\
\hline 3 & Tarif yang di tawarkan sangat terjangkau & 4.25 & 4.26 & 1.002 \\
\hline 4 & Karyawan berpenampilan rapi, menarik dan memiliki attitude yang baik & 4.06 & 4.11 & 1.012 \\
\hline 5 & Performansi jaringan luas, lancar dan tidak ada gangguan & 4.69 & 4.69 & 1.000 \\
\hline 6 & Kemudahan dan kecepatan administrasi saat melakukan transaksi pembayaran & 4.07 & 4.09 & 1.005 \\
\hline 7 & Proses pemasangan sangat mudah dan cepat & 4.14 & 4.14 & 1.000 \\
\hline 8 & Selalu tepat waktu dalam memberikan pelayanan & 4.12 & 4.12 & 1.000 \\
\hline 9 & $\begin{array}{l}\text { Layanan yg iperoleh pelanggan sudah sesuai dengan informasi dan promo yang } \\
\text { diberikan }\end{array}$ & 3.99 & 4.16 & 1.043 \\
\hline 10 & $\begin{array}{l}\text { Karyawan melayani dengan ramah terhadap informasi yang di butuhkan pelanggan } \\
\text { melalui call center yang telah tersedia }\end{array}$ & 3.97 & 4.05 & 1.020 \\
\hline 11 & Cepat dan tanggap dalam merespon keluhan atau gangguan layanan di pelanggan & 4.26 & 4.26 & 1.000 \\
\hline 12 & Tanggap dalam memberikan informasi dan promo terbaru terhadap pelanggan & 4.01 & 4.17 & 1.040 \\
\hline 13 & $\begin{array}{l}\text { Pelanggan mendapatkan kemudahan dalam melakukan pemutusan berlangganan } \\
\text { sewaktu-waktu }\end{array}$ & 4.02 & 4.02 & 1.000 \\
\hline 14 & Menjamin kemudahan pelanggan untuk update \& upgrade fitur-fitur terbaru & 4.00 & 4.06 & 1.015 \\
\hline 15 & Memberikan pergantian perangkat yang rusak secara gratis & 4.06 & 4.06 & 1.000 \\
\hline
\end{tabular}


Tabel 5. Improvement Ratio (Lanjutan)

\begin{tabular}{|c|l|c|c|c|}
\hline No & \multicolumn{1}{|c|}{ Pernyataan } & CSP & Goal & Nilai IR \\
\hline 16 & Memiliki jam operasi sesuai kebutuhan pelanggan & 3.96 & 4.06 & 1.025 \\
\hline 17 & $\begin{array}{l}\text { Memiliki karyawan yang bisa memberikan perhatian secara personal } \\
\text { kepada pelanggan }\end{array}$ & 3.94 & 4.01 & 1.018 \\
\hline 18 & $\begin{array}{l}\text { Karyawan memahami keinginan dan kebutuhan pelanggan terkait } \\
\text { informasi dan komunikasi }\end{array}$ & 3.58 & 4.02 & 1.123 \\
\hline
\end{tabular}

${ }^{*} \mathrm{CSP}=$ Customer Satisfaction Performance

\section{Sales point}

Sales point seperti yang ditunjukkan pada tabel 6 adalah daya jual yang dimiliki oleh sebuah produk berdasarkan seberapa menguntungkan kebutuhan pelanggan tersebut berdampak pada perusahaan jika kebutuhan tersebut terpenuhi. Sales point mempunyai nilai dari salah satu diantara tiga nilai berikut: $1.0=$ Tanpa titik penjualan, 1.2 = Titik penjualan menengah, dan 1.5 = Titik penjualan kuat (Cohen, 1995)

7. Raw weight dan normalize raw weight

Raw weight berisi nilai dari data dan keputusan yang diambil dari kolom-kolom bagian matriks perencanaan sebelumnya.
Nilai raw weight adalah sebagai berikut: Raw weight $=($ important to customer $/$ ITC $) X$ (improvement ratio/IR) X (sales point/SP)

Selanjutnya dari nilai raw weight yang telah diperoleh dilakukan pembobotan untuk memperoleh nilai normalize raw weight dengan rumus

Normalized raw weight $=$ raw weight $/$ raw weight total

Tabel 6. Raw weight dan normalize raw weight

\begin{tabular}{|c|c|c|c|c|c|}
\hline Pernyataan ke & $I T C$ & $I R$ & $S P$ & $R W$ & $N R W$ \\
\hline 1 & 4.30 & 1.000 & 1.5 & 6.45 & 0.062 \\
\hline 2 & 4.14 & 1.041 & 1.5 & 6.47 & 0.062 \\
\hline 3 & 4.25 & 1.002 & 1.2 & 5.11 & 0.049 \\
\hline 4 & 4.06 & 1.012 & 1.2 & 4.93 & 0.048 \\
\hline 5 & 4.69 & 1.000 & 1.5 & 7.04 & 0.068 \\
\hline 6 & 4.07 & 1.005 & 1.2 & 4.91 & 0.047 \\
\hline 7 & 4.14 & 1.000 & 1.5 & 6.21 & 0.060 \\
\hline 8 & 4.12 & 1.000 & 1.5 & 6.18 & 0.060 \\
\hline 9 & 3.99 & 1.043 & 1.5 & 6.24 & 0.060 \\
\hline 10 & 3.97 & 1.020 & 1.5 & 6.08 & 0.059 \\
\hline 11 & 4.26 & 1.000 & 1.2 & 5.11 & 0.049 \\
\hline 12 & 4.01 & 1.040 & 1.2 & 5.00 & 0.048 \\
\hline 13 & 4.02 & 1.000 & 1.2 & 4.82 & 0.047 \\
\hline 14 & 4.00 & 1.015 & 1.5 & 6.09 & 0.059 \\
\hline 15 & 4.06 & 1.000 & 1.5 & 6.09 & 0.059 \\
\hline 16 & 3.96 & 1.025 & 1.2 & 4.87 & 0.047 \\
\hline 17 & 3.94 & 1.018 & 6.02 & 0.058 \\
\hline 18 & 3.58 & 6.03 & 0.058 \\
\hline
\end{tabular}

\section{Penentuan Karakteristik Teknis dan Prioritas Karakteristik Teknis}

Karakteristik Teknis atau Respon Teknis ini merupakan solusi terhadap kebutuhan-kebutuhan pelanggan. Solusi ini menggambarkan sistem yang akan dibuat dan sekaligus menunjukkan kemampuan apa saja yang akan diberikan pihak oleh pihak manajemen dalam mengatasi kebutuhan pelanggan. Respon teknis juga merupakan jawaban dari permasalahan yang ada pada setiap atribut/pernyataan sebelumnya. 
Karakteristik teknis yang telah disusun selanjutnya diolah untuk melihat target teknis apa yang akan diutamakan oleh Telkom Indihome. absolute Importanc$$
=
$$

$\sum_{n}^{i}($ Relationship Value X Customer Importance $)$

Prioritas utama diperoleh dengan menentukan besarnya nilai absolute menggunakan rumus :

Tabel 8. Data respon teknis, absolute importance

\begin{tabular}{|c|c|c|c|}
\hline No & Respon Teknis & $\begin{array}{c}\text { Absolut } \\
\text { Importance }\end{array}$ & Rangking \\
\hline 1 & Pemasangan instalasi jaringan Fiber Optik sesuai dengan spesifikasi & 155.43 & 1 \\
\hline 2 & Pemilihan perangkat untuk kapasitas bandwidth & 37.26 & 11 \\
\hline 3 & Adanya kelas Fiber Academy untuk pelatihan penambahan skill teknisi & 0 & 17 \\
\hline 4 & Adanya perangkat cadangan disetiap STO & 145.44 & 2 \\
\hline 5 & Pemilihan sales / bagian pemasaran yang tepat & 40.68 & 8 \\
\hline 6 & Adanya pengawalan tingkat gangguan dan penyelesaiannya & 40.16 & 9 \\
\hline 7 & Terdapat teknisi disetiap STO & 0 & 18 \\
\hline 8 & Adanya pemberian diskon atau promo & 74.97 & 4 \\
\hline 9 & Adanya personil help desk dengan shift 24 jam & 38.25 & 10 \\
\hline 10 & Penerapan ISO pada Security & 75.42 & 2 \\
\hline 11 & Pemberian akses hanya pihak yang berwenang & 11.82 & 15 \\
\hline 12 & Adanya pemiliharaan jaringan & 35.73 & 12 \\
\hline 13 & Pemasangan perangkat indoor dan outdoor yang tepat & 74.61 & 5 \\
\hline 14 & Melatih kemampuan help desk secara teknik & 73.35 & 6 \\
\hline 15 & Pemberian restitusi sewaktu ada gangguan & 32.22 & 13 \\
\hline 16 & Adanya e-learning product knowledge & 4.25 & 16 \\
\hline 17 & Adanya Alker dan Sarker yang lengkap & 12.90 & 14 \\
\hline 18 & Adanya Penerapan KDO & 42.21 & 7 \\
\hline
\end{tabular}

Dari Tabel diatas dapat diketahui urutan prioritas usulan perbaikan kualitas layanan Telkom Indihome yang dinyatakan dalam pernyataan respon teknis sebagai berikut :

1. Pemasangan instalasi jaringan Fiber Optik sesuai dengan spesifikasi

2. Adanya perangkat cadangan disetiap STO

3. Adanya kelas Fiber Academy untuk pelatihan penambahan skill teknisi

4. Adanya pemberian diskon atau promo

5. Pemasangan perangkat indoor dan outdoor yang tepat

6. Melatih kemampuan help desk secara teknik

7. Adanya Penerapan KDO
8. Pemilihan sales / bagian pemasaran yang tepat

9. Adanya pengawalan tingkat gangguan dan penyelesaiannya

10. Adanya personil help desk dengan shift 24 jam

11. Pemilihan perangkat untuk kapasitas bandwidth

12. Adanya pemiliharaan jaringan

13. Pemberian restitusi sewaktu ada gangguan

14. Adanya Alker dan Sarker yang lengkap

15. Pemberian akses hanya pihak yang berwenang

16. Adanya e-learning product knowledge

17. Adanya kelas Fiber Academy untuk pelatihan penambahan skill teknisi

18. Terdapat teknisi disetiap STO 


\section{PENUTUP}

Berdasarkan hasil penelitian yang telah dilakukan, diketahui bahwa rata-rata tingkat Kepuasan layanan Indihome di witel Sidoarjo sebesar 4,09 dari 5 skala linkert. Sedangkan untuk kompetitor dari MNC rata-rata sebesar 4,04 dan First Media rata-rata sebesar 4,06. Meskipun rata-rata tingkat kepuasan Indihome lebih tinggi dibandingkan dengan kedua kompetitornya namun tetap perlu dilakukan perbaikan dari beberapa aspek. Langkahlangkah perbaikan yang dapat dilakukan diantaranya adalah pemasangan instalasi jaringan Fiber Optik sesuai dengan spesifikasi, adanya perangkat cadangan disetiap STO dan adanya kelas Fiber Academy untuk pelatihan penambahan skill teknisi

Untuk penelitian selanjutnya dapat ditambahkan benchmarking dengan perusahaan layanan broadband lainnya sehingga dapat diketahui secara pasti posisi perusahaan yang diteliti bila dibandingkan dengan semua competitor yang ada.

\section{DAFTAR PUSTAKA}

Cohen, L. (1995). Quality Function Deployment How to Make QFD Work for You. AddisonWesley Publishing Company, Reading, Massachusetts.

Karuniawati.,Supriyanto, Hari., S. L. M. (2005). Analisa Kepuasan Konsumen Dengan Menggunakan Implementasi Quality Function Deployment (QFD).

Rowter, K. (2017, April). Perang Tarif Broadband Murah, Operator Bisa Bangkrut. Kompas.com. Retrieved from Perang Tarif Broadband Murah, Operator Bisa Bangkrut

Sugiono. (2014). Metode penelitian kuantitatif, kualitatif, dan R\&D. Alfabeta. Bandung. 